\title{
RESILIENCE IN FAMILIES IN WHICH A PARENT HAS DIED
}

\section{BERQUIN HUMAN}

Assignment presented in partial fulfilment of the requirements for the degree of Master of Arts (Counselling Psychology) at the University of Stellenbosch

Supervisor: A P Greeff PhD

December 2001 


\section{STATEMENT}

I, the undersigned, hereby declare that the work contained in this assignment is my own original work and that I have not previously in its entirety or in part submitted it at any university for a degree. 


\section{ABSTRACT}

The death of a parent calls on the family to utilize all its resources in order to adapt successfully and maintain normal family functioning. Within the mental health field a paradigm-shift from pathology-based to health-oriented is underway. Integral to this health-oriented paradigm is resilience, the ability to rebound after being stressed or challenged, as well as being able to rise above adversity and to survive stress. Family resilience theory emphasizes the role that family characteristics, behaviour patterns and capabilities play in cushioning the impact of stressful life events and in assisting the family in recovering from crises (McCubbin, Thompson, \& McCubbin, 1996). Using a crosssectional survey research design, the present study aimed to explore and explicate those resiliency factors which enable families to adjust and adapt successfully after the loss of a parent. Families in which the death of a parent took place 1 to 3 years ago, and in which the eldest child was between 12 and 19 years old were approached to take part in this study. Thirty nine families completed questionnaires, as well as an open-ended question in which they were asked to report the most important factors or strengths which they felt helped their family through the stressful period. Results indicate that intrafamilial support such as emotional and practical support amongst family members, and family hardiness characteristics such as the internal strengths and durability of the family unit, contribute to resilience within the family. Individual characteristics, such as positive personality characteristics like optimism, are as important. Support from extended family and friends, as well as support obtained from religious and spiritual beliefs and activities, were reported as facilitating successful adjustment to the loss. 


\section{OPSOMMING}

Die dood van 'n ouer vereis dat 'n gesin alle bronne moet benut ten einde suksesvolle aanpassing en gewone gesinsfunksionering te handhaaf. Binne die geestesgesondheidsveld is daar ' $n$ paradigma-verskuiwing vanaf patologie-gebaseerd na gesondheidsgeoriënteerd. Integraal tot hierdie gesondheidsgeoriënteerde paradigma is veerkragtigheid, die vermoë om terug te bons, uit te styg, en te oorleef nadat teëspoed ervaar is. Gesinsveerkragtigheidsteorieë beklemtoon die rol wat gesinseienskappe, gedragspatrone en bekwaamhede speel met betrekking tot die versagting van die impak van stresvolle lewenservaringe, asook die gesin se herstel na die krisis (McCubbin, Thompson, \& McCubbin, 1996). 'n Dwarssnit opname-navorsingsontwerp is gebruik om die veerkragtigheidsfaktore te identifiseer en te beskryf wat gesinne help om suksesvol na die dood van 'n ouer aan te pas. Gesinne waar 'n ouer tussen een en drie jaar vantevore gesterf het, en die oudste kind tussen 12 en 19 jaar oud is, is genader vir deelname aan hierdie ondersoek. Nege-en-dertig gesinne het vraelyste sowel as ' $n$ oop-end vraag voltooi waarin hulle gevra is om die belangrikste faktore te beskryf wat hul gesin deur die stresvolle periode gehelp het. Resultate dui daarop dat intragesinsondersteuning soos emosionele en praktiese ondersteuning, en gesinsgehardheid met kenmerke van interne sterkte en die volhoubaarheid van die gesin as eenheid, bygedra het tot gesinsveerkragtigheid. Individuele eienskappe soos optimisme het net so 'n essensiële rol gespeel. Ondersteuning van familie en vriende, asook ondersteuning as gevolg van godsdienstige en spirituele oortuigings en aktiwiteite, was fasiliterend in die suksesvolle aanpassing na die dood van 'n ouer. 


\section{ACKNOWLEDGEMENTS}

I wish to extend my thanks to $\operatorname{Dr}$ A P Greeff for his enduring patience and steady faith, to my wife and parents for their continual support and encouragement, and to my Heavenly Father who made all of this possible. 


\section{CONTENTS}

LIST OF TABLES. ii

INTRODUCTION. 1

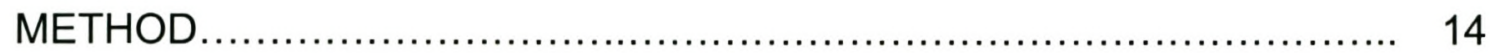

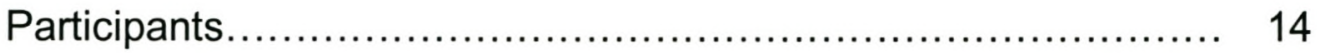

Measuring Instruments........................................ 15

Procedure............................................................ 18

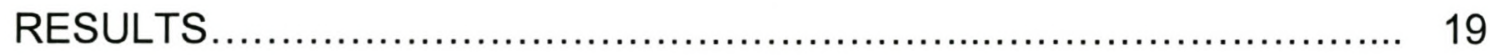

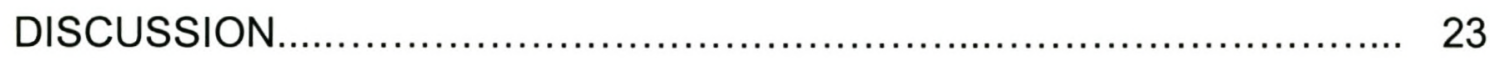

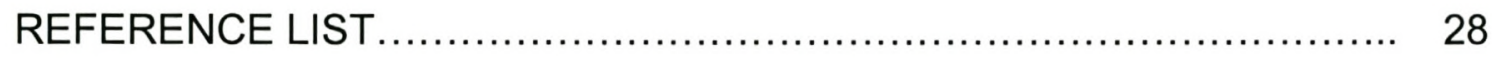




\section{LIST OF TABLES}

Page

1. Internal and External Coping Resources as Reported by the

Families ( $\mathrm{N}=39$ ) (Parent and Adolescent combined)

2. Pearson Product-Moment Correlations between Family Sense of

22

Coherence (FSOC) and Potential Resiliency Variables 


\section{INTRODUCTION}

All families will encounter the death of an immediate family member - a powerful experience that shakes the foundation of family life and leaves no member unaffected (Jordan, Kraus \& Ware, 1993; Walsh, 1998). A death in the family requires change or adjustment from both adults and children (Nelson, 1982), making the experience the most stressful life event that families face (McKenry \& Price, 1994). Although the grieving process is a normal response to death, there can be physical, psychological, and social consequences for surviving family members that can be viewed as stressor experiences (Burnell \& Burnell, 1989). It has been estimated that one third of all major bereavement leads to problems where professional help may be required (Raphael, 1984). The bereaved often experience heightened levels of social and emotional adjustment problems (Nelson, 1982) and parental loss in childhood has been considered a risk factor in adult psychopathology (Mäkikyrö et al., 1998).

Death within a family is a source of profound stress and calls on the family to utilize all its resources in order to cope with it adequately and maintain balance and harmony. Certain characteristics of family members' interactive processes and patterns of functioning allow them to face adversity and challenges in their lives and survive. Most literature dealing with family relations does not contain adequate data about coping mechanisms for dealing with the loss of a family member. Generally, research on death has focused on the experience of death and dying and its negative implications for the family (Janosik \& Green, 1992). This is largely due to the deficit-oriented approach that has been the dominant paradigm in the field of mental health. Much of the research on families and health has tended to pathologize families, implicating the family in the cause or maintenance of nearly all problems in individual functioning (McKenry \& Price, 1994). This focus on family pathology originates both from early family therapy research that studied how family dysfunction could cause mental illness, 
and from medical research that searches for pathogens and other 'causative' factors (McKenry \& Price, 1994).

More recently, the strengths and resilience of families have been emphasized. Antonovsky developed the Salutogenic paradigm, which proposes that stressors are part of human existence, and it is as important to investigate successful coping (origins of health) as it is to investigate the origins of pathology (Antonovsky \& Sourani, 1988). Rather than looking at factors associated with deficits, salutogenesis is concerned with discovering characteristics that contribute to healthy functioning in families (Hawley \& DeHaan, 1996). This is an optimistic and forward-looking perspective. Families are viewed as challenged rather than damaged, an approach that questions the myth of the problem-free family and focuses on family regeneration and capacity for self-repair.

Resilience is associated with a salutogenic orientation toward psychological health. Derived from Latin roots, resilience means "to jump (or bounce) back" (Silliman, 1994, p. 2), thus implying an ability to return to an original form after being bent, compressed or stretched, as well as being able to rise above adversity and to survive stress (Hawley \& DeHaan, 1996; Walsh, 1996). Family resilience describes the path a family follows as it adapts and prospers in the face of stress, both in the present and over time. Family resilience theory emphasizes the role that family characteristics, behaviour patterns and capabilities play in cushioning the impact of stressful life events and in assisting the family in recovering from crises (McCubbin et al., 1996). This study aims to identify resilience factors that enable families to move through bereavement by adapting and adjusting successfully despite the loss.

Researching families that have coped with loss by death is important because few studies have focused on the coping patterns and sources of resilience in single-parent families (Heath \& Orthner, 1999). Research of this nature can add to our understanding of why some families are resilient and how they are able to embrace family crises as 
manageable challenges rather than insurmountable tragedies. Furthermore, a paucity of research exists looking at how the family as a unit may be resilient and how that may affect therapy (Hawley, 2000). This calls for more studies since the concept of resilience can be presented as a valuable framework to guide research, intervention and prevention efforts. Understanding key processes can help clinicians to mobilize untapped resources, enabling distressed families to cope effectively through their mutual support and collaboration (Walsh, 1996). Examining resiliency factors will add to current theories and also reveal limitations of resiliency models. These limitations can then be addressed and the theories and frameworks can be refined and improved. Capacity for resilience is innate and as such we are able to develop social competence, problem-solving skills, a critical consciousness, autonomy, and a sense of purpose (Benard, 1995). Research on resilience has the possibility of giving families going through life transitions a sense of purpose and a belief in the future, including goal direction, educational aspirations, achievement motivation, persistence, hopefulness, optimism, and spiritual connectedness.

In the literature grief is conceptualised most often as an individual response to loss with little attention paid to family processes. In the years of research on families under stress, the focus of this cumulative work has been on the identification, conceptualisation, measurement, and validation of the protective and recovery factors operative in resilient individuals (Dugan \& Coles, 1989; Luthar \& Zigler, 1991; Masten, Best \& Garmezy, 1990; Simeonsson, 1995; Werner-Wilson, Zimmerman \& Whalen, 2000). As a result of this approach the mental health field has failed to appreciate the impact of loss on the family as an interactional system. Clinical attention to bereavement has focused on individual mourning processes much more than on the grief reactions of the family (Walsh, 1998). Family resilience theory goes beyond a contextual view of individual resilience to a family-system level, focusing on relational resilience in the family as a functional unit (Walsh, 1996). Resilience is conceptualised as the 
combination of individual characteristics and relationship patterns of interactions within the family. It is thus necessary to recognize that both individual and relational factors are operating and that these must be considered simultaneously.

McCubbin, Thompson, and McCubbin (1996) were the pioneers in shifting the focus of resilience as internal and external factors associated with the individual, to an examination of resilience as it is experienced in families. The Resiliency Model of Family Adjustment and Adaptation, developed by McCubbin (1988) and his colleagues, attempts to explain why, when faced with transitions and crises, some families are able to recover while other family systems fall apart and deteriorate under the same circumstances (McCubbin et al., 1996). According to this model, resilience is defined as "the positive behavioural patterns and functional competence individuals and the family unit demonstrate under stressful or adverse circumstances, which determine the family's ability to recover...[by] restoring the well-being of family members and the family unit as a whole" (McCubbin, Thompson, Thompson, \& Futrell, 1999, p. 142). Within this framework resilience is viewed as involving two distinct but related family processes. Firstly, adjustment that involves the influence of protective factors in facilitating the family's ability and efforts to maintain its integrity, functioning, and fulfil developmental tasks in the face of risk factors. A family experiencing a stressor will thus be motivated by the resulting tension created by the crisis to adjust its patterns of functioning in order to restore harmony and balance. Secondly, adaptation involves the function of recovery factors that promote the family's ability to "bounce back" and adapt in family crisis situations. Adapting entails the process of altering the environment, the community and the family's relationship to the community to restore the family's harmony, balance and well-being (McCubbin et al., 1996).

Consequently, family resilience research has focused on addressing the central and complex issues of determining what protective factors are critical to family adjustment in the 
face of specific risks or cluster of risk factors, as well as what recovery factors are critical to family adaptation in the face of specific family crisis situations. However, McCubbin et al. (1996) emphasise that while families have been studied in both the adjustment and the adaptation phases of the Resiliency Model, few results have indicated a need for separate emphasis on either. Instead, as McCubbin, McCubbin, Thompson, Han, and Chad (1997) have reiterated, family systems call upon and utilise all their resources in crisis situations. In view of this, the Resiliency Model depicts the entirety of the family systems' response to stress - the interaction of family problem solving and coping, family resistance resources, social support and family coherence - as the family attempts to restore stability. These resources that assist the family in meeting the demands of a loss will now be discussed in further detail.

Family hardiness is described by McCubbin et al. (1996) as an adaptational resource. Family hardiness is characterized by the internal strengths and durability that a family unit demonstrates during times of crises. A family's sense of commitment to overcoming the crisis, its efforts to be active rather than passive, and its sense of being in control of the crisis are all components of hardiness. These characteristics of hardiness, as stress resistant and adaptational resources in families, could act as mediating factors in mitigating the effects of stressors and demands and facilitate adjustment and adaptation over time (McCubbin et al., 1996).

A family's sense of commitment to overcoming the crisis can be expressed in the cooperation between family members. When family members co-operate, they strengthen their ability to overcome adversity by forming relational resilience. Relationships are strengthened when a crisis is viewed as a shared challenge to be confronted together. This affiliation between family members can create an atmosphere of trust in times of trouble, which can foster resilience. As Beavers and Hampson (1990) have proposed, families are best able to 
weather adversity when members have an abiding loyalty and faith in one another, rooted in a strong sense of trust. This "togetherness" can also lead to an emotional bonding between family members, described as family cohesion (Olson, 1993; Sigelman \& Shaffer, 1995). Cohesion creates the opportunity for family members to turn to one another for emotional and practical support, and collaboration during times of crisis. Each member of the family can participate in easing family burdens or providing comfort, and each is helped by being included in a functional way. The comfort and security provided by warm, caring relationships can help buffer stressors (Walsh, 1998). However, it is important that family members counterbalance unity, mutual support, and collaboration with the separateness and autonomy of the individual member. Patterns of extreme family enmeshment or disengagement can become problematic. Enmeshed families often demand absolute togetherness and become intolerant of individual differences that are seen as threats to group survival. In contrast, disengaged families tend to avoid the pain of loss with distancing and emotional cut-offs, leaving members isolated in their grief. Adaptation to loss is facilitated when families balance closeness and commitment with tolerance for separateness and differences (Walsh, 1998).

Another characteristic of family hardiness is its sense of being in control of the crisis. This characteristic can facilitate or constrain the adaptational response to the stressor. How a family appraises the crisis, the distress, and its recovery resources, influences its sense of being in control (Lazarus \& Folkman, 1984). Consequently, adapting to a crisis situation is influenced by the views families hold about their successes and failures. It was found that high resilient families view mistakes or failure as experiences from which to learn, rather than as occasions of defeat (Walsh, 1998). They attribute mistakes to factors they can change, such as not enough effort or an unattainable goal. The more competent a family feels, the more in control it feels in the situation (Walsh, 1998). In contrast, families lacking in resilience 
attribute their mistakes to their own deficits and believe that these deficiencies cannot be changed.

A family's determination to be active and persevere in the face of overwhelming adversity, is another component of family hardiness. However, this active perseverance must be counterbalanced with the realisation about what can be controlled during a crisis and accepting what cannot. Resilience requires acceptance of limits and then putting best efforts into what is possible. Walsh (1998) states that mastering a crisis can be seen in terms of process. Family members may not be able to control the outcome of events, but they can make choices and find meaningful ways to participate actively in the process of unfolding events. They can change aspects they can influence. For example, when no treatment options remain and death is at hand, family members can actively choose ways to participate in caregiving, the relief of suffering, and preparation for death. In such ways, they make the most of the time they have together and find comfort in loving one another well in the face of loss (Walsh, 1998).

The death of a family member can cause a major shift in a family's worldview of the specific crisis, with reverberations for both immediate reorganization and long-term adaptation of the family. How families make sense of a crisis such as the loss of a family member, and endow it with meaning, is most crucial for familial resilience (Antonovsky \& Sourani, 1988). A family's sense of loss can be influenced by its sense of coherence. Family sense of coherence can be defined as a global orientation to life as comprehensible, manageable, and meaningful. A strong sense of coherence fosters confidence in the family's ability to clarify the nature of problems so that they seem ordered, predictable, and explicable. Demands are believed to be manageable, mobilizing useful resources, including relational resources. Stressors are viewed as challenges that the family is motivated to deal with successfully. Viewing a crisis as comprehensible, manageable, and meaningful can assist a family to adapt 
to events that affect and transform family and social structures (Patterson \& Garwick, 1994a). A high sense of family coherence can promote stability and health, helping families to reach higher levels of reorganisation and adjustment after the crisis (Antonovsky \& Sourani, 1988).

Underlying each of these three components of coherence are core processes that facilitate adjustment and adaptation to a crisis. Communication facilitates the comprehensibility of a crisis. Sharing the experience of death, dying, and loss can promote both immediate and long-term adaptation for family members, strengthening the family as a functional unit (Walsh, 1998). Open and honest communication is an essential element in grief resolution (Gilbert \& Smart, 1992; Jordan et al., 1993; Wolin, 1998). The ability to communicate openly and honestly is of vital importance for family resilience over the entire course of the loss process, but particularly in the transitional difficulties of the immediate aftermath (Walsh, 1998). During this period, intense emotions may surface at different moments, including complicated and mixed feelings of anger, disappointment, abandonment, helplessness, relief, guilt, and confusion. Because of the change in family structure, ambiguity in messages about blurred boundaries and role expectations may surface, all of which can foster depression and block mastery of challenging situations (Boss, 1991). Family members' abilities to express and respond to needs and concerns, and to negotiate system change to meet new demands at crisis points, is crucial to family resilience (Walsh, 1998). Clear, open and direct communication between family members, empathy for one another's positions, tolerance of conflict, and a readiness to grapple with differences when they occur, are essential factors that increase the resilience of the family in dealing with a loss (Bloch, Hafner, Harari \& Szmukler, 1994). These factors facilitate family adaptation and strengthen the family as a supportive network for its members (Walsh, 1998). In a study on the adjustment of children after the loss of a parent, it was found that children who experienced open communication with the surviving parent, reported fewer depressive symptoms and a 
decrease in state anxiety (Raveis, Siegel \& Karus, 1998). Anderson et al. (1992) found that for adolescents facing risk factors, open communication with parents was seen as a strong protective factor that predicted adjustment. Thus, if sharing of information and an open expression of feelings about the deceased fosters comprehensibility of the loss experience, healthy adaptation to parental loss is more likely to occur (Raveis et al., 1998).

Manageability is the second core element of family sense of coherence and can be described as the family's efforts to reach and maintain an equilibrium that will lead to balance, harmony, and recovery after the initial crisis. The death of a family member invariably changes the structure of the family and distorts established patterns of interaction. In order to obtain a state of equilibrium that is conducive to balance, harmony, and recovery, the family is compelled to manage these changes and distortions by reorganizing and reinvesting in other relationships and life pursuits, and by changing its patterns of functioning including roles, rules, meanings, and lifestyles (Bloch et al., 1994). This process of management is influenced by the family's ability to be flexible. Flexibility is the capacity to change when necessary, an element that encourages high functioning in couples and families (Satir, 1988). Families that have lost a member through death commonly experience an immediate period of rapid disorganization, which is disorienting and chaotic. Change is alarming, mainly because family members fear that they might loose control of their lives in a runaway process that might leave them even worse off than they are in their present predicament. Family resilience requires the ability to be flexible enough to counterbalance stability and change as family members go through crises and challenges (Walsh, 1998). Some families allow for too much change and become chaotic. A chaotic and disorganized family structure will make it difficult for the family to maintain enough stability and continuity to manage the transitional upheaval. Other families allow too little change after the family structure has been altered by loss. An overly rigid family structure will resist modifying set patterns to make the necessary 
accommodations to loss (Walsh, 1998). A flexible balance between stability and change maintains a stable family structure while also allowing for change in response to life's challenges (Beavers \& Hampson, 1993; Olson, 1993). Manageability is not only fostered by the family's ability to be flexible, but also by its ability to maintain set patterns of functioning. During times of crisis, disruption in such set patterns of functioning like rituals and daily routines can intensify upset and confusion. Rituals and routines provide a sense of stability that can help a family to manage the transitional upheaval. They also provide a family with a sense of continuity over time by linking past, present, and future through shared traditions and expectations (Walsh, 1998). Daily routines such as family dinner and bedtime stories can provide the family members with regular contact and order (Hochschild, 1997). Rituals to mark the loss of a life and a loved one, such as a funeral and anniversary-visits to the grave can bind the family together by sharing grief, and receiving comfort in the supportive network of the community of survivors (Imber-Black, Roberts, \& Whiting, 1988).

A sense of coherence addresses the meaningfulness of a crisis within the broader context of life. For families who must cope with chronic conditions, their beliefs shape their definition of the condition and help them develop coping strategies that are associated with positive psychological outcomes (Patterson \& Garwick, 1994b). Families can cope with crisis and adversity by making meaning of their experience by linking it to their social world, to their cultural and religious beliefs, to their multigenerational past, and to their hopes and dreams for the future. Beliefs shape who we are and how we understand and make sense of our experience (Walsh, 1998). Belief systems include values, convictions, attitudes, biases, and assumptions, which combine to form a set of basic premises that trigger emotional responses, inform decisions, and guide actions. Families develop shared belief systems that are connected to cultural values and influenced by their position and experiences in the social world over time (Falicov, 1995). Such shared belief systems organize experience to enable 
family members to make sense of crisis situations. The dominant beliefs in a family system hold a very strong influence on how a family as a functional unit will deal with adversity. Core family beliefs such as "We never give up when the going gets tough", or "Men don't cry" are fundamental to family coping strategies (Walsh, 1998). Accordingly, a family's belief system can be facilitative and increase options for problem resolution, healing, and growth, or constraining which leads to problems and restricts options (Wright, Watson, \& Bell, 1996).

Religious and spiritual beliefs can provide meaning and purpose in times of crisis (Beavers \& Hampson, 1990). Religions are organized belief systems with shared moral values and beliefs and involvement in a religious community (Wright et al., 1996). The original root of the word religion - 'religio', to bind together - has dynamic significance. During times of loss, religion may help bind together the fragments of one's life, restoring some sense of coherence and meaning (Parrot, 1999). Spirituality on the other hand can be equated with internal values that provide a sense of meaning, inner wholeness, and connection with others. A belief in a supreme being or in oneness with nature are examples of spirituality, all of which can be experienced within or outside formal religious structures. Spirituality is a fundamental form of resilience in that it provides the individual with the ability to understand and overcome stressful situations (Angell, Dennis \& Dumain, 1998). Recent research has shown the important role that religion and spirituality play in the coping process. Frantz, Trolley, and Johll (1996) examined the role of religion and spiritual beliefs in the grieving process and found that $77 \%$ of their subjects quoted that their religious and spiritual beliefs were significantly related to positive coping and future outlook and of considerable help in their grief. Similarly, Park and Cohen (1992) reported that coping through religion resulted in less distress. Congregational support can be particularly helpful during a crisis. Reed and Sherkat (1992) reported that church attendance reduces depression in a significant way by raising the self-esteem of individuals; although this occurred only if attendance 
enhanced social integration, the social support was put to use and the support was expressed with affection. It was also found that reading about and believing in God helped widows cope with the loss of their loved one (Brubaker, 1990).

Support from relatives, friends, and the community can facilitate adaptation to the death of a family member. Family isolation and a lack of social support and community connections make loss more difficult to bear and contribute to dysfunction under stress. Relatives, close friends, and social networks provide both practical assistance and vital community connection. They provide information, concrete services, support, companionship, and relief. Very importantly, they provide a sense of security and solidarity (Walsh, 1998). Community activities and religious affiliation such as participation in church activities, social clubs, and community outreach programmes, foster individual and family well-being. Reed and Sherkat (1992) have found that the opportunity for, and the using and quality of, social support, significantly enhance self-esteem and reduce depression. Having someone available when one needs support makes the future look more hopeful; being satisfied with the support received promotes positive feelings.

Economic resources can buffer the family's loss experience and influence adaptation (Walsh, 1998). This is especially true if finances have been drained by costly protracted medical care and if economic resources were lost with the death of a parent. Socio-economic status is an important factor in determining healthy family adaptation and functioning because it determines the capacity of the family to control and support children and other family members through a crisis situation and developmental changes. It was found that bereaved children in families with higher incomes and with parents that perceived their finances as adequate, were less likely than those from less-affluent families to exhibit sleep disturbances, and had fewer difficulties in concentration and fewer learning problems over a 2-year followup period (Raveis et al., 1998). With regard to socio-economic status, research has provided 
evidence that parental education has a direct bearing on the parents' ability to provide the family with adequate exposure to knowledge and problem solving skills (Heath \& Orthner, 1999).

In conclusion, healing and resilience in the face of loss depends not only on individual characteristics, but on a combination of all family processes. Therefore, a systemic framework is crucial to examining the reverberations of death within a family. An understanding of family adaptational challenges in loss and key interactional processes in recovery can guide theory, research, practice, intervention, and prevention of personal or family problems after a loss.

From the literature it is plausible to conclude that family resilience in crisis situations depends on the degree of successful adaptation achieved by the family. Internal strengths such as a family's ability to collaboratively face a crisis and to be active rather than passive, fosters a family's hardiness. The worldview a family has towards a crisis, seeing it as comprehensible, manageable, and meaningful fosters family coherence and resilience. Very importantly, external support from relatives, friends, and the community can facilitate adaptation to the death of a family member.

The experience of dying is not the same for an accident victim, a person with AIDS, a person who commits suicide, and someone who dies instantaneously of a heart attack. Neither is the experience of bereavement the same for their survivors (Papalia \& Olds, 1992). Yet all people are human, and just as there are commonalities in our lives, there are commonalities in adjusting and adapting to the death of a loved one. The aim of the present study is to understand the processes and factors that facilitate adjustment and adaptation to the death of a parent. The results of this study will contribute to a better understanding of the universal factors that bring into being the potential of all families to be resilient. 


\section{METHOD}

A cross-sectional survey research design was used to identify and describe family resilience factors. Self-report questionnaires were completed by the surviving parent and an adolescent child as representatives of the family.

\section{Participants}

Fourth year postgraduate Psychology students at the University of Stellenbosch, who were enrolled for the Family Psychology module in 2000 and 2001, had to identify a single parent family who fulfilled the inclusion criteria, approaching them for participation in the research project. The students who were unable to identify such a family asked either their family or friends to help them to find such a family. A total of 39 families participated in this investigation. All of the identified families fulfilled the following inclusion criteria of the investigation:

- the eldest child had to be an adolescent (12 to 19 years old) and still living at home

- the death of a parent had to have taken place 1 to 3 years ago

- the surviving parent should not currently be involved in a committed relationship or have remarried

- both the surviving parent and the adolescent child have to participate in the investigation.

Of the participating families $23(59 \%)$ were Afrikaans and $16(41 \%)$ were English. The majority of the surviving parents were female $(n=32 ; 82 \%)$ and $7(18 \%)$ were male. The mean age of the parents participating was $46.15(S D=5.29)$. Of the participating adolescents 26 $(67 \%)$ were girls and $13(33 \%)$ were boys. The average age of the adolescents was 16.03 $(S D=2.52)$. The mean length of marriage before the death of the other parent was 17.97 years $(S D=6.22)$ and the average time that has elapsed since the death of the parent was 3.32 years $(S D=1.89)$. There was an average of three children per family $(S D=1.13)$. Twelve 
$(31 \%)$ of the families had other dependants permanently living with them. The majority of the parents had a degree $(n=14 ; 35.90 \%)$ or a diploma $(n=11 ; 28.21 \%) ; 10(25.64 \%)$ had completed their high school education and $3(7.69 \%)$ had only a primary school education. Of the families participating in this study, 5 (12.8\%) reported an income of under R20 000 per annum. Of the remaining, 1 (2.6\%) earned between R21 000 and R40 000; 6 (15.4\%) earned between R41 000 and R60 000; 10 (25.6\%) earned between R61 000 and R80 000; 9 (23.1\%) earned between R81 000 and R100 000; and 8 (20.5\%) earned more than R101 000 per annum.

\section{Measuring Instruments}

A biographical questionnaire was compiled to gather information regarding family composition, employment, level of education, as well as the income, age and gender of the respondent's nuclear family members. This questionnaire also included an open-ended question requesting the respondent's opinion on which factors or strengths they believed helped their family through the stressful period.

The Family Hardiness Index (FHI) developed by McCubbin, McCubbin and Thompson, was used to measure the internal strengths and durability in the family unit. Hardiness refers to a sense of control over the outcomes of life events and hardships, as well as an active rather than a passive orientation in adjusting to and managing stressful situations. This scale consists of 20 items which aim to measure the characteristics of hardiness as a stress resistant and adaptational resource in families which would act as a mediating factor in mitigating the effects of stressors and demands, and facilitate adjustment and adaptation over time (McCubbin et al., 1996). The scale consists of three sub-scales (commitment, challenge, and control) which require participants to assess on a 4-point Likert rating-scale the degree (False, Mostly false, Mostly true, True, or Not applicable) to which each statement describes 
their current family situation. The Commitment subscale measures the family's sense of internal strengths, dependability and ability to work together. The Challenge subscale measures the family's efforts to be innovative, active, to experience new things and to learn. The Control subscale measures the family's sense of being in control of family life rather than being shaped by outside events and circumstances. The internal reliability (Cronbach's alpha) of the Family Hardiness Index is .82 , and the validity coefficients ranging from .20 to .23 with criterion indices of family satisfaction, time and routines, and flexibility (McCubbin et al., 1996).

To measure the level of family coherence in terms of the internal and the external environment, the Family Sense Of Coherence (FSOC) (Antonovsky \& Sourani, 1988) scale was used. This scale is comprised of 26 semantically-differential items (7-point Likert-scale). Family coherence refers to an orientation between family members that internal and external stimuli are structured and predictable, that resistance resources are available for handling the stimuli, and that life's challenges are meaningful. The higher the level of family coherence, the better the adjustment, or satisfaction with the adjustment with the family's internal and external environment. The FSOC-scale is comprised of the subscales 'comprehensibility', 'manageability', and 'meaningfulness'. Underlying each item is the level to which the respondent interprets the world as comprehensible, manageable, and meaningful (Antonovsky \& Sourani, 1988). The scale consists of eight comprehensibility, nine manageability, and nine meaningfulness items. Fourteen of the items are 'negatively' formulated and reversed values are applied so that a high score could always be representative of strong family coherence. An internal reliability coefficient (Cronbach's alpha) of $r=.92$ is reported for the full scale (Antonovsky \& Sourani, 1988). In terms of validity a high correlation of .71 was found between the FSOC- and family adjustment scales (Antonovsky \& Sourani, 1988). 
The Relative And Friend Support Index (RFS) developed by McCubbin, Larsen and Olson, was used to measure the degree to which families use relative and friend support as a coping strategy to manage stressors and strains (McCubbin et al., 1996). This scale consists of eight items, relating to sharing problems or seeking advice from neighbours or relatives, each requiring a response on a 5-point Likert rating-scale ranging from "strongly disagree" to "strongly agree". This scale has an internal reliability of .82 (Cronbach's alpha) and a validity coefficient (correlation with the original Family Crisis Oriented Personal Evaluation Scales (F-COPES)) of .99 (McCubbin et al., 1996).

The Social Support Index (SSI), developed by McCubbin, Patterson and Glynn (McCubbin et al., 1996), was used to evaluate the degree to which families are integrated into the community and view the community as a source of support; in that the community can provide emotional support (such as recognition and affirmation), esteem support (affection), and network support (relationships with relatives) (McCubbin, McCubbin, \& Thompson, 1993). This scale consists of 17 statements which are rated on a five point scale of agreement, ranging from "strongly disagree" to "strongly agree". The Social Support Index has an internal reliability of .82 (Cronbach's alpha), test-retest reliability of .83 , and a validity coefficient (correlation with criterion of family well-being) of .40 (McCubbin et al., 1996).

The Family Crises Oriented Personal Evaluation Scales (F-COPES) was used to identify the problem solving and behavioural strategies utilized by families in crisis situations (Olson et al., 1985). This measuring instrument focuses on two levels of interaction, namely: (1) individual to family system - the way in which the family manages crises and problems internally amongst family members, and (2) family to social environment - the way in which the family manages problems outside its boundaries, but still having an influence on the family as a unit. F-COPES consists of 30 -point Likert-type items. High scores is an indication of effective positive coping behaviour. The scale consists of five subscales that are 
again divided into two dimensions namely: (1) internal family coping strategies, and (2) external family coping strategies. Internal family-coping strategies defines the way in which crises are managed by using support-resources inside the nuclear family system. External strategies refers to the active behaviour that a family adopts to elicit support-resources outside the nuclear family system (Olson et al., 1985). The internal strategies are: (1) reformulating or redefining the problem in terms of the meaning it has for the family (positive, negative, or neutral) (Cronbach Alpha $=.64)$, and $(2)$ passive appreciation - the family's tendency to do nothing about crisis situations. This avoidance response is based on a lack of confidence in own potential to change the outcome (Cronbach Alpha $=.66$ ). The external strategies are: (1) using of social support, for example friends (Cronbach Alpha $=.74)$, family members (Cronbach Alpha $=.86)$ and neighbours (Cronbach Alpha $=.79),(2)$ The search for religious support (Cronbach Alpha $=.87$ ), and $(3)$ the mobilization of the family to get and accept help (for example professional help and the use of community resources) (Cronbach Alpha $=.70)$. A test-retest reliability coefficient of .71 was obtained after five weeks, and an internal reliability coefficient (Cronbach Alpha) of .77 for the total scale (Reis \& Heppner, 1993). The construct reliability of the questionnaire was proved with a factoranalysis and a varimax-rotation of the axes. Five factors were isolated with the items' factorloadings between .36 and .74. All five factors had Eigen-values larger than one (Olson et al., 1985).

\section{Procedure}

Each of the 39 identified families were contacted by phone or visited at home. After the aim of the research project was explained to the parent and the adolescent, they were asked if their family would be willing to participate. In cases where the family could not or did not want to participate, another family was identified. Appointments were scheduled to visit the families and to collect the data. During the visits the confidentiality of the information and the 
anonymity of the participants was re-emphasised. The aim and method of the investigation was then explained to the participating parent and adolescent. They were invited to ask questions should anything not be clear to them.

Firstly, both the parent and adolescent were asked why they thought their family was able to work through the loss of a parent successfully. Once their responses to this open-ended question were obtained, questionnaires were given to the parent and the adolescent. They were required to complete them separately, but in the presence of the student researcher. With the exception of a few participants who had queries about one or two items, most participants were able to complete all the questionnaires with relative ease within 30 to 50 minutes. Upon completion of the questionnaires most participants continued their conversation about the loss of their loved one. Several of the families asked if they could obtain feedback at a later date about their results (which was done at a later stage). After the parent and the adolescent were thanked for their participation, the conversation was terminated and the student researcher departed. With the help of guidelines, the questionnaires were scored by the student researcher, and reviewed by a fellow student.

\section{RESULTS}

Results obtained from the open-ended question and five questionnaires indicate that there is a significant correlation between family sense of coherence and several potential resiliency variables. In only a few instances did parents and adolescents differ in the identification of resiliency factors. The results support existing theories and previous research on resilience (Garvin, Kalter \& Hansell, 1993; McCubbin et al., 1996; Werner \& Smith, 1993).

All thirty-nine families who participated in the study responded to an open-ended question in which they were asked to report the most important factors or strengths which they felt helped their family through the stressful period. Responses which implied recovery attempts 
by the family, or which were identified as supportive, recovery-enhancing resources, were identified and organised into two main categories: internal resources which included all the support obtainable within the immediate family, and external resources which included all the support the family obtained outside of its immediate boundaries. Each category was made up of five common themes. The frequency of responses within each theme was recorded and is reported in Table 1.

\section{Table 1}

Internal and External Coping Resources as Reported by the Families ( $\mathrm{N}=39$ ) (Parent and Adolescent combined)

\begin{tabular}{|c|c|c|}
\hline INTERNAL RESOURCES & Frequency & Percentage \\
\hline $\begin{array}{l}\text { Intrafamilial support - (emotional and practical } \\
\text { support amongst the family members) }\end{array}$ & 31 & $79 \%$ \\
\hline $\begin{array}{l}\text { Individual characteristics - (personality, self } \\
\text { support, reaching out to others, and an } \\
\text { acceptance of the situation) }\end{array}$ & 19 & $49 \%$ \\
\hline Open and honest communication & 15 & $38 \%$ \\
\hline $\begin{array}{l}\text { Maintaining family rituals and participating in } \\
\text { house chores }\end{array}$ & 10 & $26 \%$ \\
\hline Financial resources & 8 & $21 \%$ \\
\hline EXTERNAL RESOURCES & Frequency & Percentage \\
\hline Social Support - (extended family and friends) & 37 & $95 \%$ \\
\hline Religion and spirituality - (activities and beliefs) & 30 & $77 \%$ \\
\hline $\begin{array}{l}\text { Professional support - (e.g. psychologists and } \\
\text { clergy) }\end{array}$ & 10 & $26 \%$ \\
\hline Community support - (e.g. Hospice) & 9 & $23 \%$ \\
\hline Career - (e.g. job, school, and colleagues) & 7 & $18 \%$ \\
\hline
\end{tabular}


Participant responses to the open-ended question indicates that within the boundaries of the surviving family, intrafamilial assistance such as emotional and practical support amongst the members were the primary resource that helped families cope with the loss. Support from extended family members and friends were reported as the primary coping resource outside the boundaries of the family.

Pearson product-moment correlations were calculated to determine the relationships between the participants' sense of family coherence and potential resiliency variables. These correlation coefficients are presented in Table 2. 
Table 2

Pearson Product-Moment Correlations between Family Sense of Coherence (FSOC) and Potential Resiliency Variables

\section{VARIABLE}

PARENTS $(\mathrm{N}=39)$

CHILDREN ( $\mathrm{N}=39)$

\section{Family Hardiness Index (FHI)}

Commitment - (family's sense of internal strengths,

$0.397^{*}$

$0.565^{\star}$

dependability, and ability to work together)

Challenge - (family's efforts to be innovative, active, to

0.292

$0.5031^{*}$

experience new things and to learn)

Control - (family's sense of being in control of family life rather than being shaped by outside events and circumstances)

Total FHI score

$0.367^{*}$

\section{Social Support Index (SSI)}

(the degree to which families find emotional, esteem, and

network support within their communities)

Relative and Friend Support (RFS)

(the family's ability to utilize relative and friend support to manage stressors and strains)

\section{Family Crises Oriented Personal Evaluation Scales (F-COPES)}

Reframing - (family's capability to redefine stressful events in

order to make them more manageable)

Passive appraisal - (family's ability to accept problematic issues

minimizing reactivity)

Social support - (family's ability to actively engage in acquiring

support from relatives, friends, neighbours and extended family)

Spiritual and Religious support - (family's ability to acquire

spiritual/religious support)

Mobilization - (family's ability to acquire community resources and accept help from others)

Total F-COPES score

Parent Age

Years Married

Years Passed Away

0.088

0.112

Child Age

0.005

$-0.05$ 
The results indicate that, for the parents, family sense of coherence is positively correlated to the following resiliency variables: commitment (Family Hardiness Index) and the total score for the Family Hardiness Index. For the adolescents, family sense of coherence is positively correlated to all of the indices on the Family Hardiness Index: (commitment, challenge, control, and on the total index); community as a source of support (Social Support Index); and passive appraisal coping style as measured by the Family Crises Oriented Personal Evaluation Scales.

\section{DISCUSSION}

The aim of this study was to identify and explore resilience factors that have the potential to assist families to adapt and adjust to the loss of a parent. Several researchers (Antonovsky \& Sourani 1988; Garvin et al., 1993; Hawley, 2000; McCubbin \& McCubbin, 1988) found that families with a stronger sense of coherence adjust better after a crisis, and reach the same or a higher level of reorganization after the crisis period. Variables that have a significant positive correlation with family sense of coherence are identified in this study as resilience factors (Werner \& Smith, 1993).

The results of the open-ended question indicate that the most important coping resource identified by the families was social support obtained from extended family and friends (see Table 1). This is in agreement with Reed and Sherkat (1992) and Walsh (1998) who found that support from relatives and friends made it easier to bear the loss of a parent. After the parent has died, social support provides practical assistance, companionship, and a sense of security and solidarity which can assist the family to adjust to the loss. Although the above indicates strong evidence exists for the role of "relative-and-friend support" in buffering a crisis, the importance of these factors were not confirmed by the results obtained from two of the questionnaires used in this study. These two data sources were the Relative and Friend 
Support Index, and a coping style of acquiring social support from relatives and friends (F-COPES) (see Table 2). This discrepancy of results within the same study could possibly be attributed to the phrasing of the questions, and/or the difference in the scoring procedure of the subjective open-ended question and the questionnaires.

The second most important recovery-enhancing resource as reported by the families, was intrafamilial emotional and practical support (see Table 1). Seventy nine percent of families found that support between its members created a safeguard against the after-effects of the loss, and facilitated family adaptation and adjustment. The affirmation of this recoveryenhancing resource as a resilience factor is not only confirmed by previous research (Olson, 1993; Sigelman \& Shaffer, 1995; Walsh, 1998), but also by the results obtained from the commitment sub-scale of the Family Hardiness Index (see Table 2). Both the parents and the adolescents identified their family's internal strengths, and their ability to work together and to depend on each other, as fostering resilience.

Family hardiness refers to the internal strengths and durability of the family unit and is characterized by:

- a sense of commitment between its members in overcoming the crises

- an active rather than passive orientation in adjusting to and managing stressful situations

- by a sense of control over the outcomes of life events and hardships (McCubbin et al., 1996).

Both the parents $(0.37, p=0.05)$ and adolescents $(0.68, p=0.05)$ significantly identified this overall construct of family hardiness as a resilience factor. Of interest is that the adolescents also separately identified each component of family hardiness (i.e. commitment, challenge, and control) as resilience factors (see Table 2). This implies that the adolescents felt that factors that fostered resilience and their ability to adjust and adapt were attached to a family's ability to collaboratively confront their challenges with an identifiable sense of commitment to 
the family, and orientation that a crisis is a challenge, and a belief that the family is in control of its own future.

Of note is that although the adolescents identified their family's innovative and active stance toward the loss, and its ability to experience and learn new things from the loss, as a resilience enhancing factor (see Table 2, Challenge subscale of the Family Hardiness Index), they also identified a passive appraisal coping style (F-COPES) as a resilience enhancing factor. Passive appraisal implies that a family employs a passive or inactive behavioural approach towards a crisis. From these results it could be postulated that the adolescents viewed the ability to be active or passive as and when necessary, as both recovery-enhancing and essential to family resilience.

Seventy seven percent of the families identified religion and spiritual support as an important coping resource (see Table 1). Their religious and spiritual beliefs gave meaning and purpose to their experience, which lead to an understanding and an acceptance of their loss (Angell et al., 1998; Beavers \& Hampson, 1990; Parrot, 1999). These families also reported that their involvement in religious and spiritual activities such as church attendance and prayer meetings, lead to social integration and social support. Despite the importance placed on this resource, it was not confirmed as a resilience factor when evaluated by the Family Crises Oriented Personal Evaluation Scale (see Table 2), which amongst others assesses the family's involvement with religious activities and ideologies in dealing with a crisis.

Studies on families under stress have emphasized the supportive and adaptive value of open and honest communication (Gilbert \& Smart, 1992; Jordan et al., 1993; Walsh, 1998; Wolin, 1998) and adequate financial resources (Raveis et al., 1998; Walsh, 1998). The contribution of open and honest communication to family well-being was reiterated by only thirty eight percent of the families in this study. Similarly, only a small number of families 
(21\%) emphasised the buffering role played by financial stability. It is possible that the participants did not consider these factors to be recovery-enhancing when answering the open-ended question. Also, the quality of communication and the role of financial resources were not evaluated in this study through the completion of questionnaires, and therefore could not confirm the possibility of these resources being resilience factors. These aspects should be examined in further studies.

Community based social support is viewed as an important factor in family resilience (McCubbin et al., 1996). Previous studies have emphasized the importance of social support as a buffer against family crisis, and as a factor in promoting family recovery (Reed and Sherkat, 1992; McCubbin et al., 1996; Walsh, 1998). In the present study only the adolescents identified emotional, esteem, and network support from the community, as a resilience factor (see Table 2, Social Support Index). Also, less than a third of the families identified community support (e.g. Hospice) and professional support (e.g. clergy in the community) as recovery-enhancing resources (see Table 1). This should be viewed against the high value families placed on social support received from relatives and friends, intrafamilial support received from the members of the nuclear family, and religion and spirituality. This may be an indication that the families in this study preferred to utilize support from people and institutions that they were familiar with.

The literature emphasize the contribution of individual characteristics to family resilience (Simeonsson, 1995; Werner-Wilson et al., 2000). Although no questionnaire was used in this study to determine if individual characteristics could be defined as a resilience factor, forty nine percent of the families identified individual characteristics such as optimism, and the ability to support one self, as recovery-enhancing to their families (see Table 1). This sustains the present study's conceptualisation of resilience as the combination of individual 
level characteristics and relationship patterns of interactions within the family. Future studies should consider both individual and relational factors when studying resilience.

The results indicate that the age of the parent and adolescent, the number of years the couple was married prior to the loss, and the number of years that have elapsed since the death of the parent, had no effect on the adaptation and adjustment of the family unit. This can be important in the formulation of inclusion criteria for future studies.

It is proposed that the most important resilience factors highlighted in the current study, through qualitative and quantitative measures, include intrafamalial emotional and practical support (encompassing the family's ability to depend on each other, and their ability to work together), and the family's hardiness (encompassing the internal strengths and durability of the family unit).

The findings of this study provide valuable insights into the recovery factors utilized by families that have lost a parent through death. These results could be used as a database for future studies that focus on resilience factors.

A limitation of this study is that the sample utilized represents only a small sector of the heterogeneous South African population. Additionally, cultural backgrounds with their unique beliefs about the death of a parent, the manner in which the parent died and its effect on the family, and pre-morbid functioning of the family was also omitted. Future studies should consider these factors in order to further explore and validate resilience resources.

This study contributes to an understanding of resilience factors that assist family adjustment and adaptation to the loss of a parent. Through the exploration and validation of resilience variables, the usefulness of a salutogenic perspective can be extended (Der Kinderen, 2000). Families that have lost a parent can utilise already existing recoveryenhancing resources, and become more resilient. 


\section{REFERENCE LIST}

Anderson, L., Beinashowitz, J., Grossman, F.K., Finnin, L., Flaherty, M., \& Sakurai, M. (1992). Risk and resilience in young adolescents. Journal of Youth and Adolescence, 21, 529-550.

Angell, G.B., Dennis, B.G., \& Dumain, L.E. (1998). Spirituality, resilience, and narrative: Coping with parental death. Families-in-society, 79(6), 615-630.

Antonovsky, A., Sourani, T. (1988). Family sense of coherence and family adaptation. Journal of Marriage and the Family, 50, 79-92.

Beavers, W.R., \& Hampson, R.B. (1990). Successful families: Assessment and intervention. New York: Norton.

Beavers, W.R., \& Hampson, R.B. (1993). Measuring family competence: The Beavers systems model. In F. Walsh (Ed.), Normal family processes ( $2^{\text {nd }}$ ed.). New York: Guilford Press.

Benard, B. (1995). Fostering resilience in children. ERIC Digest. Retrieved August 27, 2001 from the World Wide Web: http://www.npin.org/library/pre1998/n00418.html

Bloch, S., Hafner, J., Harari, E., \& Szmukler, G.I. (1994). The family in Clinical Psychiatry. Oxford: Oxford University Press.

Boss, P. (1991). Ambiguous loss. In F. Walsh \& M. McGoldrick (Eds.), Living beyond loss: Death in the family. New York: Norton.

Brubaker, T.H. (1990). Family relationships in later life. London: Sage Publications.

Burnell, G.M., \& Burnell, A.L. (1989). Clinical management of bereavement: A handbook for healthcare professionals. New York: Human Sciences.

Der Kinderen, S. (2000). Resilience in families in which a parent has been retrenched. Unpublished masters thesis: University of Stellenbosch. 
Dugan, T., \& Coles, R. (Eds.) (1989). The child in our times: Studies in the development of resiliency. New York: Brunner/Mazel.

Falicov, C.J. (1995). Training to think culturally: A multidimensional comparative framework. Family Process, 34, 373-388.

Frantz, T.T., Trolley, B.C., \& Johll, M.P. (1996). Religious aspects of bereavement. Pastoral Psychology, 44, 151-163.

Garvin, V., Kalter, N., \& Hansell, J. (1993). Divorced women: Factors contributing to resiliency and vulnerability. Journal of Divorce and Remarriage, 21(1/2), 21-38.

Gilbert, K. \& Smart, L. (1992). Coping with fetal or infant loss: The couple's healing process. New York: Brunner/Mazel.

Hawley, D.A. (2000). Clinical implications of family resilience. The American Journal of Family Therapy, 28(2), 101-116.

Hawley, D.R., \& DeHaan, L. (1996). Toward a definition of family resilience: Integrating life-span and family perspectives. Family Process, 35(3), 283-298.

Heath, D.T., \& Orthner, D.K. (1999). Stress and adaptation among male and female single parents. Journal of Family Issues, 20(4), 557-585.

Hochschild, A. (1997). Time bind. New York: Holt.

Imber-Black, E., Roberts, J., \& Whiting, R. (Eds.). (1988). Rituals in families and family therapy. New York: Norton.

Janosik, E., \& Green, E. (1992). Family life, process and practice. Boston: Jones and Bartlett Publishers.

Jordan, J.R., Kraus, D.R. \& Ware, E.S. (1993). Observations on loss and family development. Family Process, 32, 425-440.

Lazarus, R., \& Folkman, S. (1984). Stress, appraisal, and coping. New York: Springer. 
Luthar, S., \& Zigler, E. (1991). Vulnerability and competence: A review of research on resilience in childhood. American Journal of Orthopsychiatry, 61, 6-22.

Mäkikyrö, T., Sauvola, A., Moring, J., Veijola, J., Nieminen, P., Järvelin, M.R., \& Isohanni, M. (1998). Hospital treated psychiatric disorders in adults with single-parent and two-parent family background: A 28-year follow up of the 1966 Northern Finland birth cohort. Family Process, 37(3), 335-345.

Masten, A., Best, K., \& Garmezy, N. (1990). Resilience and development: Contributions from the study of children who overcome adversity. Development and Psychopathology, 2. 425-444.

McCubbin, H.I., \& McCubbin, M.A. (1988). Typologies of resilient families: Emerging roles of social class and ethnicity. Family Relations, 37, 247-254.

McCubbin, H.I., McCubbin, M.A., \& Thompson, A.I. (1993). Resiliency in families: The role of family schema and appraisal in family adaptation to crises. In Brubaker, T.H. (Ed.), Family relations: Challenges for the future (pp. 153-177). Newbury Park: Sage.

McCubbin, H.I., Thompson, A.I., \& McCubbin, M.A. (1996). Family assessment: Resiliency, coping and adaptation - Inventories for research and practice. Wisconsin: University of Wisconsin Publishers.

McCubbin, H.I., McCubbin, M.A., Thompson, A.I., Han, S., \& Chad, T. (1997). Families under stress: What makes them resilient. AAFCS Commemorative Lecture. Retrieved July 5, 2001 from the World Wide Web: http://www.cyfernet.org/research.resilient.html

McCubbin, H.I., Thompson, E.A., Thompson, A.I., \& Futrell, J.A. (1999). The dynamics of resilient families. London: SAGE Publishers.

McKenry, P.C., \& Price, S.J. (1994). Families and change: Coping with stressful events. London: SAGE Publishers. 
Nelson, G. (1982). Coping with the loss of father: Family reaction to death or divorce. Journal of Family Issues, 3(1), 41-60.

Olson, D.H., McCubbin, H.I., Barnes, H., Larsen, A., Muxen, M., \& Wilson, M. (1985). Family inventories: Inventories used in a national survey of families across the family life cycle ( $2^{\text {nd }}$ ed.). St. Paul: University of Minnesota.

Olson, D.H. (1993). Circumplex model of marital and family systems. In F. Walsh (Ed.), Normal family processes $\left(2^{\text {nd }}\right.$ ed.). New York: Guilford Press.

Papalia, D.E., \& Olds, S.W. (1992). Human Development (5 $5^{\text {th }}$ ed.). New York: McGrawHill, Inc.

Park, C.L., \& Cohen, L.H. (1992). Religious beliefs and practices and the coping process. In: B. Carpenter (Ed.), Personal coping: Theory, research, and application. New York: Praeger.

Parrot, L. (1999). Grieving the death of a spouse. Journal of Psychology and Christianity, 18(4), 330-337.

Patterson, J.M., \& Garwick, A.W. (1994a). Theoretical linkages: Family meanings and sense of coherence. In H. McCubbin, E. Thompson, A. Thompson, \& J. Fromer (Eds.), Sense of coherence and resiliency: Stress, coping, and health. Madison: Center for Excellence in Family Studies, University of Wisconsin.

Patterson, J.M., \& Garwick, A.W. (1994b). Levels of family meaning in family stress theory. Family Process, 33, 287-304.

Raphael, B. (1984). The anatomy of bereavement. London: Hutchinson \& Co.

Raveis, V.H., Siegel, K., \& Karus, D. (1998). Children's psychological distress following the death of a parent. Journal of Youth and Adolescence, 28(2), 165-180.

Reed, M.D., \& Sherkat, D.E. (1992). The effects of religion and social support on selfesteem and depression on the suddenly bereaved. Social Indicators Research, 26, 259-257. 
Reis, S.D., \& Heppner, P.P. (1993). Examination of coping resources and family adaptation in mothers and daughters of incestuous versus non-clinical families. Journal of Counselling Psychology, 40(1), 100-108.

Satir, V. (1988). The new peoplemaking. Palo Alto, CA: Science \& Behaviour Books.

Sigelman, C. \& Shaffer, D. (1995). Life-span and human development $\left(2^{\text {nd }}\right.$ ed.). California: Brookes/Cole Publishing Company.

Silliman, B. (1994). Resiliency research review: Conceptual \& research foundations. National Network for Family Resiliency. Retrieved July 24, 2001 from the World Wide Web: http://www.cyfernet.org/research/resilreview.html

Simeonsson, R. (1995). Risk, resilience, and prevention: Promoting the well-being of all children. Baltimore: Brookes.

Walsh, F. (1996). The concept of family resilience: Crisis and challenge. Family Process, 35(3), 261-281.

Walsh, F. (1998). Strengthening family resilience. New York: The Guilford Press.

Werner, E.E., \& Smith, R.S. (1993). Vulnerable but invincible: A study of resilient children. New York: McGraw-Hill.

Werner-Wilson, R.J., \& Zimmerman, T.S., \& Whalen, D. (2000). Resilient response to battering. Journal of Contemporary Family Therapy, 22(2), 161-187.

Wolin, S.J. (1998). Project Resilience. Retrieved June 15, 2000 from the World Wide Web: http://www.projectresilience.com/framesconcepts.htm

Wright, L., Watson, W.L., \& Bell, J.M. (1996). Beliefs: The heart of healing in families and illness. New York: Basic Books. 